But the most destructive industry, so far as the forests are concerned, is the manufacture of bast mats, bark boots (lapti), cordage, and other articles prepared from the liber or inner bark of the lime, birch, and willow, chiefly of the former tree. It is computed that $100,000,000$ pairs of lapti are made annually, each pair requiring the bark of four young trees; thus $400,000,000$ trees are cut down every year for shoes! Lime-trees from five to ten years of age, and half-grown birch, are employed for this purposc. Such reckless waste is much to be regretted; and $\mathrm{Mr}$. Werekha otserves that the pines are tapped for their resin and bled to death in from ten to fifteen years, in the same way as the Landes of Gascony were denuded of their pine-forests during the last century.

The previously almost useless aspen, either for fuel or building, has attained to considerable importance within the last few years as a material for paper-making. There are already ten manufactories actively engaged in the preparation of this paper in Russia, and two in Finland; and as vast reserves of this tree have accumulated in the forests, it is expected to prove a source of great riches for many years to come. Timber, of course, is the most valuable article exported, though resinous products and bast mats bring in a large sum. The Scotch pine, spruce fir, birch (for coach-building), and the oak, are the principal and almost the only timbers exported. Speaking of the giant oaks of Russia, Mr. Werekha becomes almost sentimental, for they form the strength of British and French shipbuilders, and occasionally revisit their native country in a form by no means fiattering to national pride, as the Russians are still very small shipbuilders.

\section{THE INDIA IIUSEUM*}

THE India Museum, at present located at Whitehall, has long been known for its extensive and valuable collections of Indian products, a collection too valuable, indeed, not to have been made more available, both for scientific and commercial purposes, than it has been. The removal, however, of the specimens to the galleries at South Kensington will bring them within the reach of ordinary mortals who have neither bodily strength nor inclination to make a pilgrimage to the topmost floor of one of the highest buildings in London.

The importance and value of these collections has to some extent been shown in the several reports which have from time to time been issued from the foreign Office. Dr. Forbes Watson, as Reporter on the Products of India, has done much service in this respect, and Dr. M. C. Cooke, who has drawn up the present report, is no novice amongst Indian gums and resins, having gained an extensive experience from his long official connection with the Muscum.

There are, no doubt, many products of the Indian forests that ought to be included in European commerce, but from the want of a proper knowledge of their uses, have never established themselves in the market. Individually, we have often deplored the prevailing prejudice amongst commercial men in favour of old and well-known commoditics, amounting sometimes even to the absolute rejection of new products, without giving such products a fair trial. Dr. Forbes Watson, in an introductory note to the report under consideration, in reference to this, says it should "be remembered that gums or resins sent over for valuation in the London market are necessarily subject to comparison and competition with the very best qualities of the same substances which come into any of the European markets, and that careful collection is not a too frequent characteristic of Indian products:" Dr. Watson further points out that it is of very great importance to the existing and future trade of India that

* Report by Dr. M. C. Cooke, on the Gums, Resins, Olco-resins, and resinous products in the India Museum, or produced in India. Prepared under the direction of the Reporter on the Products of India, 1874. samples should be sent home in sufficient quantity for report, since this is the only means by which they can be brought under the notice of competent authorities. For this purpose it is suggested that in the casc of gums, resins, \&c., quantities of from 20 lbs. to 25 lbs. would be sufficient for distribution amongst brokers and traders, as well as for analysis and experiments. The necessity, also, of obtaining accurate information on the botanical source of the plant yielding any particular product is strongly urged. The value of accurate specimens gathered at the time of collecting the article itself, whether it be gum, resin, wood, or fibre, must be apparent to everyone, and is strongly advocated in the article "Botany" in the "Admiralty Manual." In all cases such specimens should consist of leaves, flowers, and, where possible, fruits also, securely labelled and numbered, so that no mistake may occur.

This report of Dr. Cooke's is valuable, as it brings together nearly all that has been written on the gums and resinous products of India. The botanical synonymy of each species, with references, is first given; next, a short botanical description; then its habitat, native names, history, description, and uses; and finally, in the case of the most important products, references to the works where the subject has been treated of. Dr. Cooke has brought his report down to the most recent period, for we find under the genus Garcinia, of which the species are described as yielding gum, a description of $G$. Griffithii, with the following note:- "Anderson says of this plant that there is in Maingay's herbarium a plant very like it in habit, but described by him as having a circumsciss anther, which is cultivated in Singapore as the true gamboge of Siam. There still appears to be some doubt as to the source of Siam gamboge, which Dr. Hooker seems disposed to attribute to this tree." The fact is, that in the most recent revision of the order, Garcinia Griffithii of Anderson has been considered identical with $G$. morella, var. pedicellate, to which Siam gamboge has been referred by Hanbury, and which Dr. Hooker thinks has sufficiently distinctive characters to raise it to the rank of a species under the name of $G$. Hanbunyi. Again, Dr. Cooke refers to the very recent work of Flückiger and Hanbury, in which Siam gamboge is attributed to $G$. morelic, var. pedicellata, as stated above. Indeed, throughout the report there are frequent references to the "Pharmacographia," but we are not a little surprised that Stewart and Brandis's "Forest Flora" is not quoted. Thus, for instance, at p. 24 of the report, the Marking Nut, Sonccurpus anacardium, is dismissed with very few lines: while in the "Forest Flora" is an excellent description of the tree; of the wood, which "is full of an acrid juice which causes swelling and irritation, so that the timber cutters object to fell it unless it has been ringed for some time;" and of the fruit and the black varnish, which is prepared from the pericarp, and which is used mixed with lime-water for marking cotton. Small consignments of these fruits occasionally arrive in this country, and not long since a quantity of a very fine kind came into the hands of a London house. I. R. J.

\section{UMBELLULA, OR CLUSTER POI YP}

$A$ BOUT six months since (vol. x. p. 142) we referred to a letter from Prof. Wyville Thomson, in which he mentions having brought up from a depth of nearly I,500 feet, between Prince Edward's Island and the Crozets (Kerguelen's Land), specimens of an Umbcllula. When the Challenger was between the coasts of Portugal and Madeira, several specimens of another species of the same rare genus, but from a depth of about 2,000 feet, were also dredged up. The history of these curious Cluster Polyps is interesting. Some hundred and twenty years ago, and some one and twenty years before $M$. Kerguelen discovered the land now bearing his name, 
Capt. Adriaanz, the master of the whaling-ship Britamia, being then in lat. $79^{\circ} \mathrm{N}$, and about eighty miles from Greenland, on pulling up his sounding line, found two specimens of a large plant-like polyp clinging to it ; the length of the stem of the larger specimen was six feet, and he noted that the expanded flower-like polyp which was at one end of the stem was of a fine bright yeliow colour. Struck by their size and beauty, and the strangeness of such creatures living at a depth in the sea of more than 220 fathoms, he brought them home to his friend $\mathrm{Mr}$. Dunze, of Bremen, who had been a pupil of the illustrious Haller. Mr. Dunze gave the smaller specimen to Christlob Mylius, a Professor of Botany at Leipzig, and the larger to Peter Collinson, F.R.S. ; this latter gentleman gave it to John Ellis, of zoophyte fame, to describe, which he did in the Philosophical Transactions for 1752 , accompanying his description with a plate. What became of this specimen is unknown. Mylius's one found its way into a collection in Göttingen, and was not to be found there by Pallas in 1766 . No specimens being found for thus more than a century, an air of uncertainty hung round this Cluster Polyp, and its portrait, so often copied in our text-books, seemed to be all one was likely to know about it. It was, therefore, with the greatest delight that the writer of these lines, in the summer of 1872 , saw two specimens of Umbellula in the Swedish Museum of Natural History at Stockholm; one rare object after another had been shown to him by Prof. Lovén; but the Umbellula, though the last, was not the lcast of the treasures accumulated therein by this esteemed professor, who stated that Mr. J. Lindahl had dredged them up during the expedition of H.S.M. Ingegerd and Gladan to the Greenland Seas in I87I. Within the last few days we have received from Stockholm a quarto memoir, "Om Pennatulid-slägtet Umbellula af Josua Lindahl," with three plates. This memoir was read before the Royal Swedish Academy in February 1874, and describes the two specimens as two species, under the names of $U$. miniace and $U$. pallida. Prof. Kolliker has also described one of the species found during the Challonger expedition as $U$. Thomsoni, making four species of the genus now described. It is marvellous what changes have taken place in our knowledge of the Natural Sciences in the interval between the description of Ellis's species and those so excellently described and figured in the memoir before us. 'T tre other genus Grinilium of the family Umbelluline, found about I858 in a depth of 2,700 fathoms in the Banka Sea, will, we trust, be re-discovered by Prof. Wyville Thomson. It is only known by a fragment of the stem in the Leyden Museum, the crown of polyps having fallen overboard as Capt. Siedenburg, after whom the species is called, was pulling in the line to which it clung.

E. P. W.

\section{SCIENCE IN THE ARGENTINE REPUBLIC*}

$7 \mathrm{HE}$ Bulletin of the National Academy of Exact Sciences of Cordova, of which the three first numbers have lately reached this country, gives us an interesting account of a new endeavour of the well-known naturalist, Dr. Burmeister, to introduce scientific studies into his adopted country. In I 868 Dr. Burmeister pre-

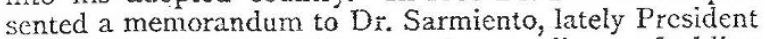
of the Argentine Republic, upon the expediency of adding a Faculty of Mathematical and Physica! Sciences to the National University of San Carlos in Cordova. In response to this appeal authority was given to Dr. Burmeister by the Minister of Public Instruction to import eight professors from Germany to establish the Faculty; and Dr. Burmeister himself was appointed Special Commissioner for the purpose, and eventually Director of this branch of the University. For a long time, Dr. Burmeister

* Boletin de la Academia Nacional di Ciencias Exactas existentente en la Universidad de Cordova. Entregas I, 2, and 3. Buenos Aires, I874, tells us, his exertions to obtain a staff of professors from his old colleagues in Halle were unsuccessful. The novelty of the idea and the distance of Buenos Ayres rather stood in the way of his offers being accepted. At length, in 1870 , two of the vacant posts were filled by the arrival of Dr. Max Sicwert to occupy the chair of Chemistry, and of Dr. P. G. Lorrentz to fill that of Botany. In the following year the assistance of Dr. G. H. Weyenbergh, of Haarlem, was obtained for the chair of Zoology, and that of Dr. Sellack for the professorship of Medicine. Not until $1 S 73$ was the staff finally completed by the appointment of Dr. Vogler to the professorship of Mathematics. In the same year, as we understand from Dr. Burmeister's report, the plans for the construction of the new buildings necessary for the University were finally approved of by the National Congress, and the works are now in process of execution.

From notices which subsequently appear in the Bulletin we fear that Dr. Burmeister has met with some difficulties in controlling his staif of professors. This can be hardly wondered at when the novelty of the plan is considered, and the difficulty of getting eight persons, strangers to each other, to work together to establish a new institution in a far distant country, where a foreign tongue is spoken. We have little doubt, however, that under Dr. Burmeister's supervision all will ultimately right itself, and that the Academy of Exact Sciences of Cordova will become an institution higbly creditable to the enlightened rulers of the Argentine Republic, who have established the National Observatory under the direction of the distinguished astronomer Dr. Gould in the same city.

That some progress has already been made in the cultivation of the natural sciences in Cordova is apparent by several papers contributed to the first three numbers of the Bulletin, amongst which are essays "On the Land and Fresh-water Molluscs," by Dr. Dö̈ring ; "On certain genera of Microlepidoptera," by Dr. Berg ; "On the Vegetation of the province of Tucuman," by Dr. Hicronymus; and "On the Salinas of Buenos Ayres," by Dr. Schickendautz.

\section{NOTES}

A't the suggestion of the Conncil of the Royai Geographical Society, a mantual will be prepared for the use of the Arctic Expedition, consisting of reprints of papers in the transactions of learned societies which would not otherwise be accessible, and other materials; the object being to fumish an exact view of the state of existing knowledge of Greenland and the surrounding scas. The geographical and ethnological portions will be under. taken by the Arctic Committee of the Geographical Society. The other sections will be edited by Mr. Rupert Jones, under the supervision of a Committee of the Royal Society. The appointments of the lieutenants and other officers to the Axctic Expedition were made this week. The Royal Society has re. commended the appointment of a botanist and a zoologist for the consideration of the Admiralty, but they have not yet been officially selected. Good progress is being made in the strengthexing of the ships at Portsmouth, which have been ordered to be ready for sea by the middle of May. 'The statenent, in some of our contemporaries, that Capt. E. Hobart Seymour is to be second in command of the Expedition, is incorrect.

MANY sorts and conditions of men will regret as a perional loss the death of the Rev. Charles Kingsley, which took place on Saturday last. We regret his loss as that of a man who had a warm love for science, and who by his writings and example has done much to foster a love for it among others. He was an honour to his country and his cloth, and it would be a good thing for the latter in many ways if its members could be persuaded to follow his example, and, like him, take a hearty 